\title{
Different Ways to Apply a Measurement Instrument of E-Nose Type to Evaluate Ambient Air Quality with Respect to Odour Nuisance in a Vicinity of Municipal Processing Plants
}

\author{
Bartosz Szulczyński ${ }^{1}$, Tomasz Wasilewski ${ }^{2}$, Wojciech Wojnowski ${ }^{3}$, Tomasz Majchrzak ${ }^{3}$, \\ Tomasz Dymerski ${ }^{3}$, Jacek Namieśnik ${ }^{3}$ and Jacek Gębicki ${ }^{1 \text {,* }}$ \\ 1 Department of Chemical and Process Engineering, Chemical Faculty, Gdansk University of Technology, \\ 11/12 G. Narutowicza Str., 80-233 Gdańsk, Poland; bartosz.szulczynski@pg.gda.pl \\ 2 Department of Inorganic Chemistry, Faculty of Pharmacy, Medical University of Gdańsk, Al. Hallera 107, \\ 80-416 Gdańsk, Poland; tomwasil@gumed.edu.pl \\ 3 Department of Analytical Chemistry, Chemical Faculty, Gdansk University of Technology, \\ 11/12 G. Narutowicza Str., 80-233 Gdańsk, Poland; wojciech@wojnowski.info (W.W.); \\ tomasz.majchrzak92@gmail.com (T.M.); tomasz.dymerski@pg.gda.pl (T.D.); \\ jacek.namiesnik@pg.edu.pl (J.N.) \\ * Correspondence: jacek.gebicki@pg.gda.pl; Tel.: +48-58-347-2752
}

Received: 30 September 2017; Accepted: 17 November 2017; Published: 19 November 2017

\begin{abstract}
This review paper presents different ways to apply a measurement instrument of e-nose type to evaluate ambient air with respect to detection of the odorants characterized by unpleasant odour in a vicinity of municipal processing plants. An emphasis was put on the following applications of the electronic nose instruments: monitoring networks, remote controlled robots and drones as well as portable devices. Moreover, this paper presents commercially available sensors utilized in the electronic noses and characterized by the limit of quantification below $1 \mathrm{ppm} v / v$, which is close to the odour threshold of some odorants. Additionally, information about bioelectronic noses being a possible alternative to electronic noses and their principle of operation and application potential in the field of air evaluation with respect to detection of the odorants characterized by unpleasant odour was provided.
\end{abstract}

Keywords: sensors and biosensors; bioelectronic nose; robots; drones; portable devices; odorants

\section{Introduction}

Odorants are the chemical substances which stimulate the olfactory system of humans, so an odour is sensed. Some odorants are characterized by an unpleasant odour and their persistent or periodical presence in ambient air results in an odour nuisance. Such situations are classified as one of the main reasons for public complaints filed to various types of institutions [1-3]. The complexity of the problem of odour nuisance in ambient air was emphasized in a number of different reports and classified as one of the most important issues regarding environmental pollution. The human nose is a natural sensor for the detection of odorants characterized by unpleasant odour. Information about odour can be perceived by humans in a conscious and subconscious way. The odorants characterized by unpleasant odour are naturally associated with potential danger, feeling of discomfort and can cause negative psychosomatic symptoms. Thus, atmospheric emission of the gases polluted with malodorous substances constitutes a significant environmental problem [4-8]. Unfortunately, continuous economic and industrial progress of many countries significantly contributes to the increased emission of pollutants into the atmosphere. Expansion of urban agglomerations in regions where municipal processing plants, such as sewage 
treatment plants or municipal landfills, are located see increased odour problems [9-13]. These plants generate a substantial amount of substances that are harmful to the environment, characterized by various physical as well as chemical properties; some of these pollutants are odorants characterized by unpleasant odour. This situation still occurs despite the fact that many countries intensively implement modern technologies aimed at limiting the malodorous substances emitted from that type of plant. The negative influence of these compounds on the environment can result from: properties of particular chemical compounds, mutual interactions between the components of gas mixtures (the phenomenon of synergism) and atmospheric factors including air temperature, wind speed and direction, air humidity, insolation $[14,15]$. Figure 1 provides schematic information about the expansion of urban agglomerations and the related permanent or temporary odour nuisance over a particular area.

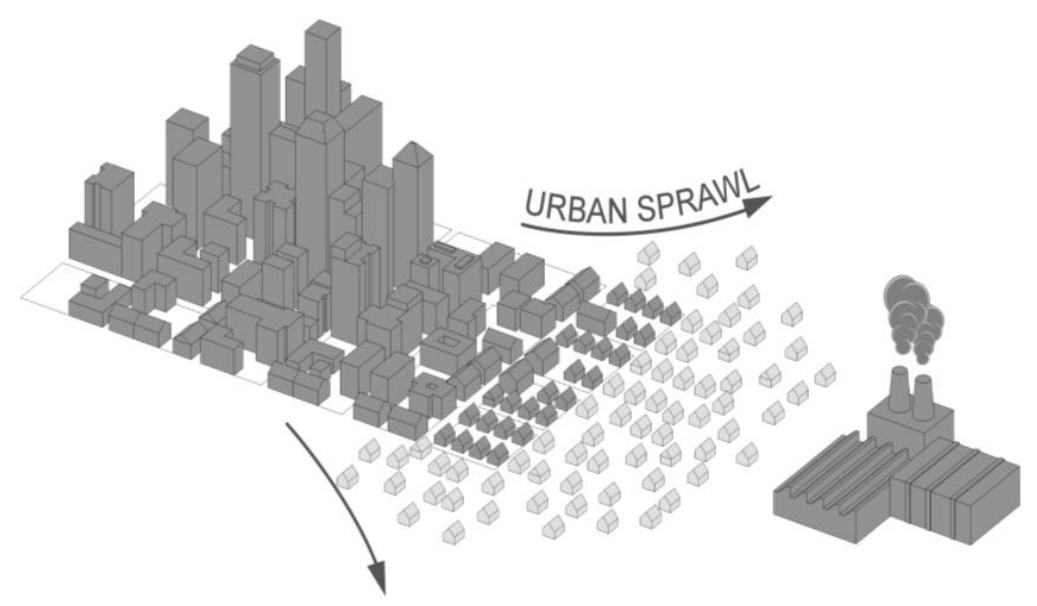

Figure 1. Schematic presentation of interaction between urban agglomeration and municipal processing plants.

The content of suitable osmophore groups in the chemical structure of odorants determines their sensory perception with respect to odour sort (what the odour of the particular odorant resembles) as well as hedonic tone (subjective opinion about the odour expressed using pleasant/unpleasant categories). Odour threshold is also a parameter describing properties of odorants. It is the minimum concentration of the odorant which stimulates the olfactory system of humans. Figure 2 presents exemplary osmophore groups of the chemical compounds that are the most frequent in the ambient air in the vicinity of municipal plants. Table 1 gathers the information about the concentrations at which odour thresholds occur [16-25].

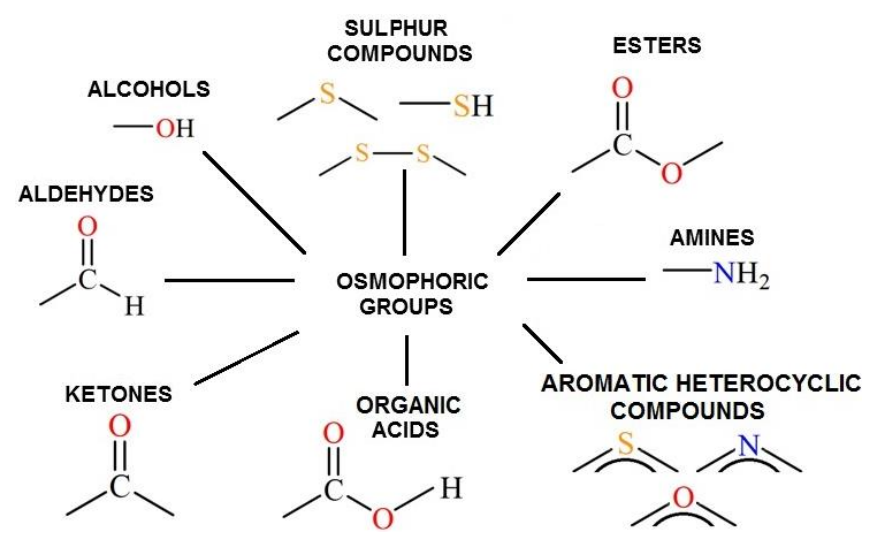

Figure 2. Exemplary osmophore groups of the chemical compounds which occur in ambient air in a vicinity of sewage treatment plants and municipal landfills. 
Table 1. Olfactory thresholds for the chemical compounds detected in the vicinity of municipal processing plants [26-28] containing particular osmophore groups.

\begin{tabular}{cccc}
\hline Osmophoric Group & Example Compound & Odour Threshold Value & Reference \\
\hline \multirow{3}{*}{ Alcohols } & methanol & $33 \mathrm{ppm}$ & {$[26]$} \\
& ethanol & $55 \mathrm{ppm}$ & {$[27]$} \\
& propanol & $6 \mathrm{ppm}$ & {$[27]$} \\
\hline \multirow{3}{*}{ Aldehydes } & formaldehyde & $0.83 \mathrm{ppm}$ & {$[28]$} \\
& acetaldehyde & $0.21 \mathrm{ppm}$ & {$[16]$} \\
& n-butylaldehyde & $0.67 \mathrm{ppb}$ & {$[26]$} \\
\hline \multirow{3}{*}{ Ketones } & acetone & $13.5 \mathrm{ppm}$ & {$[20]$} \\
& n-butanone & $50 \mathrm{ppm}$ & {$[26]$} \\
& 3-pentanone & $70 \mathrm{ppm}$ & {$[26]$} \\
\hline \multirow{3}{*}{ Acids } & aceticacid & $363 \mathrm{ppb}$ & {$[27]$} \\
& propanoicacid & $5.7 \mathrm{ppb}$ & {$[26]$} \\
& butyricacid & $1 \mathrm{ppb}$ & {$[16]$} \\
\hline \multirow{2}{*}{ Esters } & ethyl acetate & $3.9 \mathrm{ppm}$ & {$[28]$} \\
& butylacetate & $0.39 \mathrm{ppm}$ & {$[28]$} \\
& methylmethacrylate & $0.21 \mathrm{ppm}$ & {$[16]$} \\
\hline \multirow{3}{*}{ Amines/amides } & methylamine & $35 \mathrm{ppb}$ & {$[26]$} \\
& trimethylamine & $0.21 \mathrm{ppb}$ & {$[16]$} \\
& dimethylformamide & $2.2 \mathrm{ppm}$ & {$[28]$} \\
\hline \multirow{3}{*}{ Sulphur compounds } & dimethylsulphide & $5.89 \mathrm{ppb}$ & {$[27]$} \\
& dimethyldisulphide & $0.16 \mathrm{ppb}$ & {$[26]$} \\
& methyl mercaptane & $2.1 \mathrm{ppb}$ & {$[16]$} \\
\hline
\end{tabular}

Currently, reduction of the emission of odorants characterized by unpleasant odour is a priority for these branches of industry which introduce odorous compounds to the atmosphere. The most effective methods of odorants characterized by unpleasant odour emission abatement include:

- prevention of malodorous compounds emission via application of the best available technology (BAT),

- implementation of deodorization systems in existing industrial plants,

- proper planning at the localization and construction stage of newly-built plants.

However, independently of the applied technology of odorants characterized by unpleasant odour emission limitation, it is necessary to provide verification via monitoring of deodorization effectiveness. Evaluation of the deodorization level can be performed via measurement of odour intensity or odour concentration at an inlet or an outlet of a given technological installation. Instrumental techniques, apart from the olfactometric techniques-dynamic olfactometry, in particular, is one of the most popular methods of odour measurement. Electronic nose technique belongs to the group of instrumental methods. Similarly to the olfactometric techniques, it utilizes holistic analysis, without a need for identification of particular components contributing to a summary odour of the mixture. This technique belongs to dynamically developing instrumental techniques and it is increasingly applied for monitoring and evaluation of the effectiveness of deodorization of unpleasant odours generated by different fields of human activity [29-36].

In this review paper, the authors would like to focus on four aspects connected with monitoring and evaluation of air odour quality in a vicinity of municipal processing plants using the electronic nose technique. Figure 3 schematically illustrates the ways in which an electronic nose is used for evaluation of ambient air quality. The first group includes stationary monitoring with a network of electronic nose instruments. Information from particular electronic nose units located in a given area is transferred to a central unit. The second group of application is remote robots and drones which are sent to the places that are inaccessible, dangerous or harmful to people. Another group are 
portable electronic nose instruments which are devices for localization of emission sources or leakages in technological installations. The fourth and final group are bioelectronic noses which, as opposed to the classic electronic noses equipped with chemical sensors, possess biosensors or biological materials sensitive to odours. This group is a promising one that is believed to be capable of replacing animals and be characterized by better selectivity than the classic electronic noses.

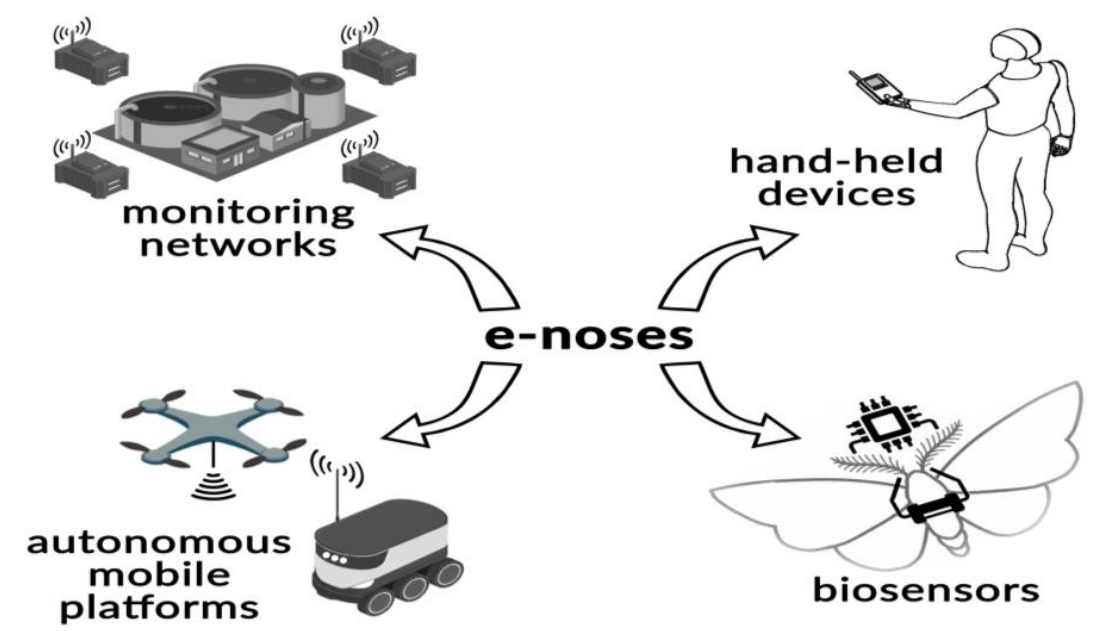

Figure 3. Schematic presentation of main applications of electronic nose instruments for evaluation of ambient air quality in a vicinity of municipal processing plants.

\section{Sensors and Biosensors Utilized in Electronic and Bioelectronic Nose Instruments Design}

Based on the information contained in Table 1, it can be noticed that volatile organic compounds (VOCs) are a dominant group of odorous compounds. These compounds, depending on the contained osmophore group, are characterized by a defined concentration range at which it is possible to identify an odour with a probability of 0.5 . The value of the olfactory threshold determines the application of a suitable chemical sensor in the electronic nose instrument in order to allow measurement at a given concentration level. A range of VOCs imission concentrations which can possibly occur in ambient air is from $0.01 \mathrm{ppb}$ to the maximum of single ppm. In this case, only a small number of the chemical sensors for VOCs measurement can fulfil the requirements concerning measurement at such a low concentration level. Electrochemical sensors, solid electrolyte semiconductor sensors and PID-type sensors are dominant chemical sensors for VOCs detection which are commercially available. Table 2 presents basic information concerning commercially available sensor types and their metrological parameters as far as measurement of the gases from VOCs group characterized by the limit of detection lower than $1 \mathrm{ppm} v / v$ is concerned $[37,38]$. 
Table 2. Commercially available chemical sensors intended for measurement of compounds from volatile organic compounds group characterized by the limit of detection lower than $1 \mathrm{ppm} v / v$.

\begin{tabular}{|c|c|c|c|c|}
\hline Manufacturer/Model & Sensor Type ${ }^{1}$ & Measuring Range & Response Time & Detected Compound \\
\hline Winsen, ME2-C2H5OH- $\Phi 16$ & EC & $0-1 \mathrm{mg} / \mathrm{dm}^{3}$ & $<20 \mathrm{~s}$ & ethanol \\
\hline Winsen, ME2-CH2O- $\Phi 16$ & $\mathrm{EC}$ & $0-10$ ppm & $<60 \mathrm{~s}$ & formaldehyde \\
\hline Environmental Sensors CO, Z-300 & $\mathrm{EC}$ & $0-30 \mathrm{ppm}$ & $<60 \mathrm{~s}$ & formladehyde \\
\hline 3ETO CiTiceL & $\mathrm{EC}$ & $0.1-20$ ppm & $<140 \mathrm{~s}$ & ethylene oxide \\
\hline Membrapor, ETO/M-10 & EC & $0.05-10 \mathrm{ppm}$ & $<140 \mathrm{~s}$ & ethylene oxide \\
\hline Uni-tec SRL, SENS-IT & MOS & $0.1-30 \mathrm{ppb}$ & nd & benzene \\
\hline Uni-tec SRL, SENS 3000 & MOS & $0-400 \mathrm{ppb}$ & $<3 \mathrm{~s}$ & methane \\
\hline UST, Triplesensor & MOS & $0.1-100 \mathrm{ppm}$ & $<100 \mathrm{~s}$ & benzene \\
\hline Alphasense, PID-A12 & PID & $0.001-50 \mathrm{ppm}$ & $<3 s$ & $\begin{array}{c}\text { VOCs with ionisation potentials }<10.6 \mathrm{eV} \\
\text { (isobutylene calibration) }\end{array}$ \\
\hline Alphasense, PID-AH & PID & $0.001-50 \mathrm{ppm}$ & $<3 \mathrm{~s}$ & $\begin{array}{c}\text { VOCs with ionisation potentials }<10.6 \mathrm{eV} \\
\text { (isobutylene calibration) }\end{array}$ \\
\hline ION Science, PPB MiniPID 2 & PID & $0.001-40 \mathrm{ppm}$ & $<3 \mathrm{~s}$ & VOCs (isobutylene calibration) \\
\hline piD-TECH eVx, Blue 045-014 & PID & $0.0005-1 \mathrm{ppm}$ & $<4 \mathrm{~s}$ & VOCs (isobutylene calibration) \\
\hline piD-TECH plus, $043-235$ & PID & $0.005-20 \mathrm{ppm}$ & $<5 \mathrm{~s}$ & VOCs (isobutylene calibration) \\
\hline
\end{tabular}


A fundamental element in the bioelectronic noses design is olfactory receptors (ORs) or cells exhibiting expression of olfactory receptor proteins which are used as an active element of the sensor in order to analyse odours with desired sensitivity and specificity. A sensitive element made of this type of biomaterial is directly connected with a sensor for odour identification and conversion of the biological signal into an analytically useful signal—electrical or optical. The sensors utilized in this type of nose are comprised of two elements-primary and secondary transducers. The first one is built from olfactory receptors cells, for instance, whereas the secondary transducer (transductor) is a non-biological device. Due to the implementation of biological elements of olfactory systems, it is possible not only to detect odorous substances at low concentration levels $[39,40]$ but also to predict the mechanisms of odours perception. Recording and processing of the biological signal can be accomplished using: microelectrode arrays (MEAs), electrochemical impedance spectroscopy (EIS), quartz crystal microbalance (QCM), field effect transistors (FET), surface plasmon resonance (SPR) sensors and conducting polymers (for example polypyrrole), carbon nanotubes, graphene and others [41].

\section{Stationary Monitoring Using Electronic Nose Network}

In the case of this type of application, the electronic noses are located over the area where the emission of odorants characterized by unpleasant odour occurs. An indispensable element of such a network is the application of data loggers which allow acquisition of complete measurement data from the sensors including raw data and a series of data describing measurement conditions and operating parameters of a device in order to verify the quality of results and improve device functioning. Thanks to transmission connections, the data logger provides scientific staff and operators who stay in an office with remote access to the e-nose installed in measurement stations. It allows on-line acquisition and verification of measurement results as well as supervision and control over the measurement process. Data loggers, due to their superior computational power as compared to the processors controlling measurement process, can perform necessary processing of measurement data. Data transmission is realized using Internet technologies, which provides easy and fast access to the e-nose instrument. Operation of stationary electronic nose instrument can be maintenance-free, and the device works in two modes:

- the first one-sampling of ambient air for ca. $1 \mathrm{~min}$,

- the second one-e-nose sensors conditioning for ca. 5-10 $\mathrm{min}$.

In the first mode, the air sucked into a sensor chamber triggers reaction of the sensors to a change in air composition. Temperature and relative humidity of air should be stabilized before entering the sensors chamber. In the second mode, there is a flow of air stream free of odorous compounds either from a bottle or from a zero air generator, instead of ambient air purified from odorous compounds. The aim is to bring the sensor's signals to their initial value (prior to measurement). The obtained signal is processed using converters and obtained information can be presented as odour concentration. A general overview of the process of sensor signal conversion into odour concentration is schematically presented in Figure 4. Precise determination of odour concentration from the information obtained using the sensors requires calibration with olfactometric methods. Such a situation results in the fact that a ratio of sensor signal changes $\Delta S$ to reference signal $S_{0}$ is not directly proportional to a ratio of odour concentration $\Delta \mathrm{C}$ to the concentration, at which olfactory threshold occurs $\left(\mathrm{C}_{\mathrm{OT}}\right)$. Maintenance of proportionality requires the application of correction $(\mathrm{k})$, which is determined using the olfactory methods. The devices activate an alarm in case of occurence of odour nuisance or instantaneous increase in odour concentration above defined admissible value. Literature provides information about such an application of an electronic nose instrument as an element of the monitoring network in a vicinity of municipal processing plants [42-44]. The information about the type of electronic nose, method of measurement, and applied data analysis can be found in Table 3. 


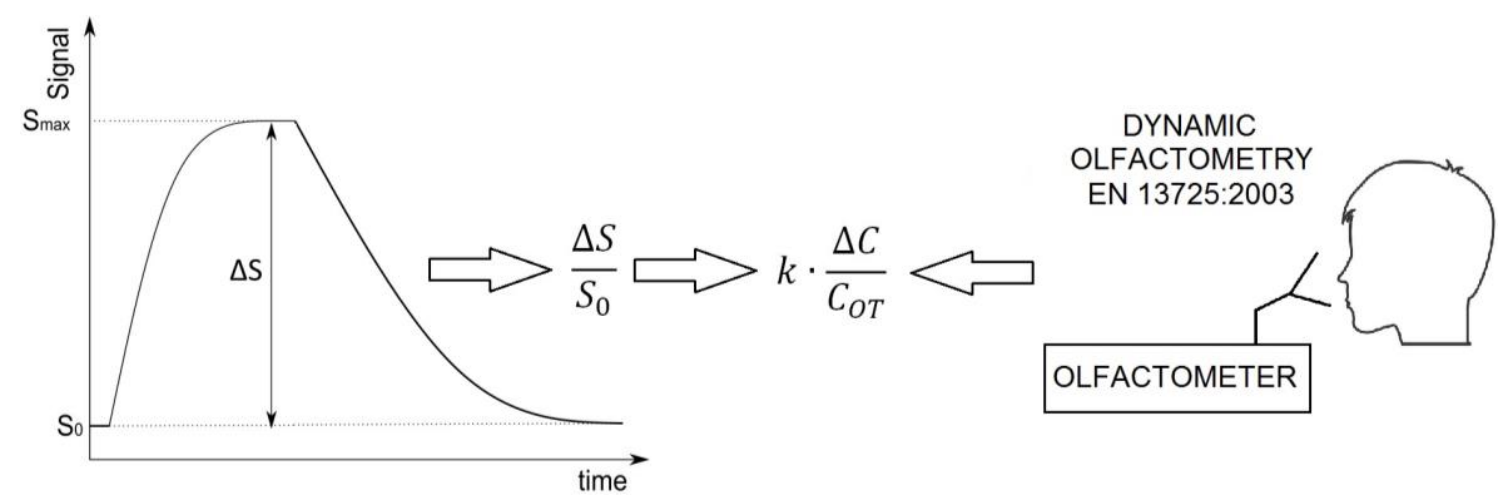

Figure 4. The process of sensor signal conversion into odour concentration.

\section{Remote Controlled Robots and Drones}

The use of electronic olfaction facilitates automation of labour-intensive measurements, such as environmental odour monitoring [45]. However, when conducting measurements in an outdoor environment, an assumption that chemical substances are moved predominantly by molecular diffusion is no longer valid, as factors such as temperature, relative humidity and, most importantly, wind speed and direction come into play. For that reason, it is difficult to predict the behaviour of the plume, even with sophisticated models and ample computational power [46]. Because of that, when collecting input data for gas distribution modelling (GDM) from a distributed network of stationary electronic noses intended for environmental monitoring data from an extended period of time, fluctuations in local atmospheric conditions are taken into account. However, there are instances in which there is a need to investigate gas distribution in an area which is not covered by a pre-existing monitoring network or to rapidly detect small, localised emissions, for instance, a leak in an industrial plant. In such a case, mobile robots equipped with electronic noses can be used to map the gas distribution in a relatively short amount of time, or even be programmed to track sources of contamination. Such an application is also relevant when reducing the cost of human labour is of major concern, or in hazardous environments where they can be used over prolonged periods of time. Mobile robots can also be potentially used to collect measurements in a tighter grid than is the case with stationary e-nose networks [47]. Electronic noses could also be mounted on existing autonomous mobile devices already used in the industry, such as robots for sampling in wastewater plants [48], further reducing the operational expense.

Furthermore, in areas which are not easily accessible even for dedicated mobile platforms, aerial drones, or even swarms thereof can be used [49,50]. Such a solution would also facilitate preparing three-dimensional GDM models, and its implementation prospects are improved by the development of new, miniaturized sensor types which could be used instead of the bulky and power-consuming MOS sensors [51,52]. The turbulent flow of air usually breaks up into discrete areas of increased concentration with little continuity to the source which means that mapping of the plume is a non-trivial task, and considerable effort is put into the development of strategies for source detection, which were described in detail by Russell et al. [53]. GDM can also be approached without any strong assumptions and simplifications regarding the character of the odour plume, instead treating sensor response signals as variables in order to obtain an overview of the gas dispersion [47]. This 'model-free' approach was likely first used by Ishida et al. to estimate the location of emission source remotely, without reaching the source itself [54]. As is the case with the construction of electronic noses and bio-electronic olfaction, the algorithms which govern the robot's path, either during mapping or localization are also inspired by nature. These include foraging and mate-seeking patterns exhibited by seabirds, lobsters, fish, bacteria and, perhaps most importantly, insects [55-58]. In particular, the behaviour of moths which move directly upwind, and upon losing the scent perform a local search until it is reacquired has been emulated in several approaches $[59,60]$. An actual olfactory apparatus of a silkworm moth 
was even integrated with a mobile robot for pheromone tracking [61]. However, it has been argued that biomimetic approaches to plume source tracking are not practical since the sensing capabilities of animals differ significantly from the electronic noses mounted on mobile platforms. Hernandez Bennetts et al. compared the chemical sensing available to both moths and robots and also investigated three different mobile platforms, both wheeled and aerial. They argued that the design of robots equipped with gas sensors should not directly follow the biological counterparts, but instead be guided by a thorough understanding of how the underlying principles of sensing and actuation principles of the animal olfactory sense [62]. Another issue is the fact that gas distribution modelling is usually used for mapping the concentration of a single gas, which in a real, outdoor environment is unrealistic. In actuality, there are numerous interferences which might impact the response signal of non- or semi-selective gas sensors and mask the presence of other sources of emission. A majority of reported attempts at equipping autonomous robots with gas sensors involved a single type of odour source, emitting a known chemical compound at a steady rate. In field use, in applications such as detection of sources of malodours, it might be necessary to use an array of several sensors and interpret their response pattern holistically-equipping the mobile platform with an electronic nose instead of a single sensor. This has been done in numerous studies, however in a number of these the e-nose mounted on a pre-existing robot body was used as just a set of different sensors, with only the signal magnitude of one of them used as input for GDM and source localization, with no statistical processing of the signal from the entire array, which does not conform to the definition put forward by Persaud and Dodd [63].

However, some attempts have been made to use an e-nose equipped robot in an environment with more than one odour type. These include several investigations involving researchers from the Center for Applied Autonomous Sensor Systems of the Örebro University, in which the capabilities of robots for odour source localization and mapping and the detection and identification of odours using an electronic nose were successfully combined [62,64-66]. In a recent work, a robot-mounted electronic nose equipped with an array of MOS sensors was used to generate a distribution map for multiple volatile compounds with a 'model-free' algorithm, together with a set of classification maps in which the estimated likelihood of detecting a given compound at a particular location is shown [47]. Such an approach could possibly find application in measuring the emission from a large, non-homogenous source of emission such as a communal landfill. A robot could also be used during landfill rehabilitation for examining the condition of the soil in a given locality. The use of electronic noses mounted on mobile autonomous devices in environmental monitoring has some promising prospective applications. A majority of research in this area is preliminary, as the challenges of using electronic olfaction in an open environment are compounded by the spatial and temporal variability of the measurements and with the necessity to develop reliable, adaptive algorithms governing the robot's behaviour. However, with the ongoing miniaturisation of gas sensors and a steady increase of computational power at our disposal, the future use of aerial drones, likely working in swarms [59], could be used to rapidly assess the odour distribution over a relatively large area with no pre-existing monitoring network. Table 3 presents exemplary applications of robots for evaluation of air quality in a vicinity of municipal processing plants.

\section{Portable Electronic Nose Instruments}

The concept of application of portable electronic nose instruments resembles utilization of remote robots and drones. The only difference is the fact that the electronic nose is transported by humans. These devices can be employed when odour concentrations are low and do not impose a hazard to human health and life. Thus, it is rather a warning device or an instrument for detection of leakages from technological lines. Moreover, portable electronic noses can be useful in odour evaluation in the cases where other analytical methods are difficult to apply. The examples can be diffuse sources, such as sheds, hangars, hen houses, tanks etc. with stagnant air, where evaluation of emitted air stream is difficult or emission fluctuates over time, which makes attribution of odour concentration to a particular time of day impossible. Metal oxide sensors, which are the most popular and widely 
available chemical sensors used in electronic olfaction, are far from ideal for use in hand-held devices for environmental monitoring due to high power consumption and susceptibility to changes in relative humidity [67] but can be easily miniaturised, especially in the case of metal oxide semiconductor field effect transistors (MOSFET) [68]. The main issue with using portable electronic noses is the fact that in environmental samples, the analytes are present at very low concentrations and cannot be easily pre-concentrated, as the implementation of purge-and-trap modules would lead to excessive power consumption and bulkiness for a hand-held device. Because of that, when the atmospheric air is introduced directly into the sensor chamber, the operator must get relatively close to the odour source in order to perform a reliable measurement. It is estimated that hand-held electronic noses exhibit approximately 10 times lower precision and 10 times higher limits of detection than stationary devices [69]. On the other hand, the use of portable and hand-held devices enables on-site screening which can be followed by an in-depth analysis in the laboratory and is particularly useful in situations which require an immediate response [70]. Some studies have focused on the use of portable e-noses for detection of malodours from animal farms and landfills [71,72], however, mixed results were obtained. For the above-mentioned reasons, a vast majority of hand-held e-noses use an enclosed, static headspace sampling system and are intended for the analysis of food and agricultural products [73-75], and models in which dynamic sampling of atmospheric air are used are intended for analysis of localised gas leaks and emissions [76]. Exemplary applications of portable electronic nose instruments for evaluation of air odour quality are shown in Table 3. 
Table 3. Examples of application of electronic nose instruments for evaluation of air odour quality in a vicinity of municipal processing plants.

\begin{tabular}{|c|c|c|c|c|c|c|c|}
\hline Application & Type & $\begin{array}{c}\text { Level of } \\
\text { Advancement }\end{array}$ & $\begin{array}{c}\text { Results Expressed } \\
\text { in Odour } \\
\text { Concentration Units }\end{array}$ & $\begin{array}{l}\text { Comparision } \\
\text { with } \\
\text { Olfactometry }\end{array}$ & Sensors & Data Processing & Reference \\
\hline \multicolumn{8}{|c|}{ NETWORK } \\
\hline Indoor/outdoor air quality & prototype & $\begin{array}{l}\text { Advanced in-situ } \\
\text { experiments }\end{array}$ & No & No & MOS & $\begin{array}{l}\text { Neural Processing } \\
\text { Blocks (NPB) }\end{array}$ & [43] \\
\hline Odour dispersions modelling & commercial & $\begin{array}{c}\text { In-situ } \\
\text { implementation }\end{array}$ & Yes & Yes & $\begin{array}{l}\text { Odotech's system, } \\
\text { OdoWatch }\end{array}$ & mapping & [44] \\
\hline Pulp and paper industry & prototype & $\begin{array}{l}\text { Calibration of } \\
\text { electronic noses } \\
\text { network }\end{array}$ & No & No & MOS & ANN & [77] \\
\hline Odour monitoring & prototype & $\begin{array}{c}\text { In-situ } \\
\text { implementation }\end{array}$ & No & Yes & MOS & $\begin{array}{l}\text { cluster analysis, } \\
\text { mapping }\end{array}$ & [78] \\
\hline $\begin{array}{l}\text { Assessment of odour annoyance } \\
\text { near a compost facility. }\end{array}$ & prototype & $\begin{array}{l}\text { Advanced in-situ } \\
\text { experiments }\end{array}$ & Yes & Yes & MOS & DFA, PLS & [79] \\
\hline $\begin{array}{l}\text { Monitoring of odours from } \\
\text { a composting plant }\end{array}$ & commercial & $\begin{array}{l}\text { Advanced in-situ } \\
\text { experiments }\end{array}$ & Yes & Yes & $\begin{array}{l}\text { EOS, Sacmi Group, } \\
\text { Imola, Italy (MOS) }\end{array}$ & kNN & [80] \\
\hline $\begin{array}{l}\text { Monitoring odour emissions from } \\
\text { an oil \& gas plant }\end{array}$ & commercial & $\begin{array}{c}\text { Advanced } \\
\text { experiments in model } \\
\text { condition }\end{array}$ & Yes & Yes & $\begin{array}{l}\text { EOS Ambiente, Sacmi } \\
\text { Group, Imola, Italy } \\
\text { (MOS) }\end{array}$ & not provided & [81] \\
\hline \multicolumn{8}{|c|}{ PORTABLE } \\
\hline Landfills odour monitoring & prototype & $\begin{array}{l}\text { Improvement of } \\
\text { electronic nose in } \\
\text { field studies }\end{array}$ & No & No & MOS & $\begin{array}{l}\text { DA, PCA, MLR, } \\
\text { PCR, PLS }\end{array}$ & [82] \\
\hline Outdoor air quality & prototype & $\begin{array}{l}\text { Basic in-situ } \\
\text { experiments }\end{array}$ & No & No & MOS, EC & mapping & [83] \\
\hline $\begin{array}{l}\text { Odour measurement around: } \\
\text { compost facilities, printing houses, } \\
\text { paint shops, wastewater treatment } \\
\text { plants, rendering plants, settling } \\
\text { ponds of sugar factories }\end{array}$ & prototype & $\begin{array}{l}\text { Basic in-situ } \\
\text { experiments }\end{array}$ & No & No & MOS & DA, PCA & [84] \\
\hline
\end{tabular}


Table 3. Cont

\begin{tabular}{|c|c|c|c|c|c|c|c|}
\hline Application & Type & $\begin{array}{c}\text { Level of } \\
\text { Advancement }\end{array}$ & $\begin{array}{c}\text { Results Expressed } \\
\text { in Odour } \\
\text { Concentration Units }\end{array}$ & $\begin{array}{l}\text { Comparision } \\
\text { with } \\
\text { Olfactometry }\end{array}$ & Sensors & Data Processing & Reference \\
\hline $\begin{array}{l}\text { Unpleasant and potentially } \\
\text { harmful odours in urban areas, } \\
\text { likely coming from residential } \\
\text { waste containers }\end{array}$ & prototype & $\begin{array}{l}\text { Basic in-situ } \\
\text { experiments }\end{array}$ & No & No & MOS & mapping & [85] \\
\hline Farm odour & prototype & $\begin{array}{l}\text { Advanced in-situ } \\
\text { experiments }\end{array}$ & Yes & Yes & MOS & ANN & [86] \\
\hline $\begin{array}{l}\text { Asphalt odour patterns in hot mix } \\
\text { asphalt production }\end{array}$ & commercial & $\begin{array}{l}\text { Basic experiments in } \\
\text { model condition }\end{array}$ & No & No & $\begin{array}{c}\text { Cyranose 320, } \\
\text { Smiths Detection Inc., } \\
\text { Edgewood, MD, USA } \\
\text { (CP) }\end{array}$ & Polar plots, PCA & [87] \\
\hline \multicolumn{8}{|c|}{ ROBOTS \& DRONES } \\
\hline Air Quality & prototype & $\begin{array}{l}\text { Basic experiments in } \\
\text { model condition }\end{array}$ & No & No & MOS & mapping & [88] \\
\hline $\begin{array}{l}\text { Localizing gas emission sources on } \\
\text { landfill sites }\end{array}$ & prototype & $\begin{array}{c}\text { Advanced } \\
\text { experiments in model } \\
\text { condition }\end{array}$ & No & No & MOS & $\begin{array}{l}\text { Polar plots \& } \\
\text { mapping }\end{array}$ & [62] \\
\hline Air Quality & prototype & $\begin{array}{l}\text { Basic experiments in } \\
\text { model condition }\end{array}$ & No & No & MOS & mapping & [89] \\
\hline
\end{tabular}

ANN—Artificial Neural Network; CP—Conducting Polymer; DA—Discriminant Analysis; DFA—Discriminant Function Analysis; kNN—k-Nearest Neighbours; MOS—Metal Oxide

Semiconductor; MLR—Multiple Linear Regression; PCA—Principal Component Analysis; PCR—Principal Component Regression; PLS—Partial Least Squares. 


\section{Bioelectronic Noses}

A subgroup of electronic noses engulfs bioelectronic noses which also possess high development potential. They can be implemented in all the fields where emitted odours or other types of chemical information call for high measurement sensitivity and selectivity. Intense development of these devices is aimed at elaboration of:

- sensors characterized by high sensitivity, repeatability, specificity and short response time,

- methods of detection of the wide spectrum of odorous substances comprising odour profile, including small size molecules ( $>300 \mathrm{Da})$,

- data processing systems enabling real-time monitoring,

- portable devices (sensor-on-chip),

- methods of production and immobilization of olfaction-inspired biomaterials on secondary transducers,

- sensor systems generating the signals similar to the ones present in biological counterparts,

- an electronic system, which would imitate human nose or brain,

- more friendly sensor systems allowing reduction of equipment and analysis costs.

Regarding sensors design, one can distinguish the bioelectronic noses with different types of sensitive element plating. It was presented schematically in Figure 5.

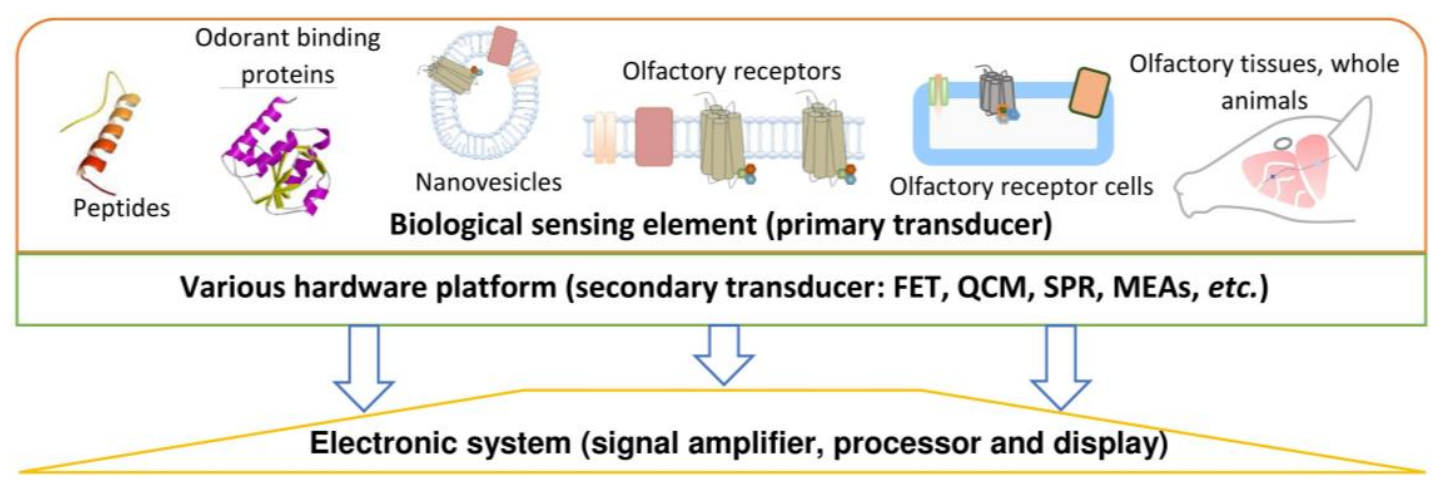

Figure 5. Schematic presentation of available biomaterials used for the construction of bioelectronic noses.

Currently the market does not offer commercial odour biosensors based on olfactory receptors, however, there are still attempts to broaden their practical application, including in the field of environmental analytics and monitoring. Concept versions of bioelectronic noses are designed to enable detection of odorants at low concentrations before their amount reaches the level dangerous for the environment. A fundamental problem connected with proper operation of bioenoses is the poor activity of biological elements in dry conditions. A solution to this problem seems to be the implementation of synthetic peptides mimicking binding sites of the olfactory receptors [90,91]. The bioenose designed by Lee et al. [92] was capable of selective detection of trimethylamine and ammonia which are considered environmentally onerous due to their strong odour. Lee et al. also demonstrated a sensor functionalized with olfactory receptor proteins, activated in dry state [93]. Additionally, the sensor exhibited the properties of the human sense of smell such as antagonism. In order to obtain a more stable tertiary structure of the olfactory receptors, proteins were trapped in a 'nanodisc', a self-assembling nano-scale membrane assembly [94]. In the future, the bioelectronic nose can significantly complement the shortages of electronic noses, especially as far as more specific and sensitive analysis of numerous environmental pollutants is concerned. Son et al. [95] presented the bioelectronic nose enabling real-time monitoring of water quality via analysis of geosmin and 2-methylisoborneol as the indicators of water contamination level. In order to eliminate the 
disadvantages of conventional methods, human olfactory receptors (hORs) were applied, which selectively bind odorants molecules; the analysis stage is not preceded by a sample preparation process. The olfactory receptors were trapped in the form of nanovesicles deposited on single-walled carbon nanotubes (swCNT) of a field-effect transistor (FET). Another example of the biosensor based on TNT-binding receptors (tryptophan-histidine-tryptophan-WHW) linked to a conjugated polymer polydiacetylene (PDA) and modified onto the surface of single-wall carbon nanotube (SWNT)-FET, which allows measurement of 2,4,6-trimethyltoluene (TNT) content in analysed air already at the level of $1 \mathrm{fM}$ was presented by Kim et al. [96]. The insect antenna-based odour sensors can be a useful tool in protection plants; they reveal significant development potential in the field of identification of plant diseases markers or early detection of fires [97,98]. Highly sensitive and fast detection of volatile chemical compounds combined with substantial miniaturization potential creates big opportunities for elaboration of the odour biosensors, which can operate in the field and in turn could facilitate and broaden their practical application in environmental monitoring and analytics. Another milestone in malodorous substances analysis can be standardization of odours which is a correlation between data obtained from sensor matrix (for example bioelectronic nose) and particular sensations connected with the smell of given odorants. The legal acts concerning odour nuisance implemented in developed countries are based mainly on the investigations utilizing sensory analysis, which are still the most popular, however, they are gradually substituted with more advanced techniques, not burdened with problems associated with sensory panels [99]. Nowadays, various investigations are carried out which are aimed at digitalization of olfactory sensations and emotions accompanying particular odours and flavours [100]. Some stages can be realized using the bioelectronic noses which most precisely imitate the principle of operation of the human sense of smell thanks to the utilization of the olfactory receptors as one of the measurement elements [101].

\section{Summary}

Legislative bodies of most highly developed countries undertake the problem of the admissible level of odorous pollutants emission. The regulations concerning measurement of emission of malodours are continuously changed and improved, and electronic noses become one of the devices admitted in reference methodologies for odours measurement [102-104]. This paper presents different ways to apply a measurement instrument of e-nose type to evaluate ambient air with respect to detection of the odorants characterized by unpleasant odour in a vicinity of municipal processing plants. This problem is very important because the expansion of urban agglomerations goes beyond safe limits resulting in exposure to odour nuisance originating from the municipal processing plants. Due to the specificity of electronic noses, the operation of these devices can be a successful complement to current techniques of odours measurement and many countries put an emphasis on this type of approach. The electronic nose can be used as a complementary device with respect to other analytical techniques, in particular sensory analysis techniques. Currently, the market offers devices for detection of odorants characterized by unpleasant odour. Moreover, they are continuously being improved and new, upgraded prototype versions are elaborated. The most crucial aspect limiting widespread application of electronic noses is lack of defined legal regulations and their standardization. In recent years an effort has been made to develop a framework for the standardization of the use of e-noses as monitoring devices. In particular, the CEN/TC264/WG41 work group aims to propose a new European standard for instrumental odour monitoring [105]. It will be focused on technical aspects of the devices, e.g., sensitivity and selectivity to odour compounds or ease of calibration, especially in the context of relating and validating the sensor response signals to the presence of odours. It will not be applicable to the measurement of hedonic values such as measurement of odour concentration, which is the task of other work groups, such as CEN/TC264/WG2, which aims to revise the EN13725 standard for determination of odour concentration by dynamic olfactometry [106].

Stability upon temperature and humidity changes, as well as sensor response drift in time are still fundamental problems connected with the sensors comprising the electronic nose instruments. 
Bioelectronic noses are met with optimism, which are a subgroup of the electronic noses. Their specificity and high sensitivity can lead to the elaboration of commercial versions. Numerous literature reports concerning fundamentals and potentialities of electronic and bioelectronic noses justify the statement that development of the methods of odours analysis is connected with the utilization of such type of devices.

Acknowledgments: The work was financially supported by the Grant No. UMO-2015/19/B/ST4/02722 from the National Science Centre.

Author Contributions: Jacek Gebicki developed the concept of the manuscript and wrote the paper, Bartosz Szulczyński, Wojciech Wojnowski, Tomasz Wasilewski, Tomasz Majchrzak have contributed individual sections, Tomasz Dymerski and Jacek Namieśnik made substantive consultations.

Conflicts of Interest: The authors declare no conflict of interest.

\section{References}

1. Bianchi, G.; Palmiotto, M.; Giavini, M.; Davoli, E. Environmental Odor Pollution: A Complex GC-MS, Olfactometry and Diffusion Modeling Approach to Define Air Quality. In Comprehensive Analytical Chemistry; Ferrer, I., Thurman, E.M., Eds.; Elsevier: Amsterdam, The Netherlands, 2013; Volume 61, pp. 97-114, ISBN 978-0-444-62623-3.

2. The Worlds Worst 2013: The Top Ten Toxic Threats: Cleanup, Progress and Ongoing Cheallenges Table. Available online: http:/ / www.worstpolluted.org/docs/TopTenThreats2013.pdf (accessed on 2 September 2017).

3. A Review of National and International Odor Policy, Odor Measurement Technology and Public Administration. Available online: https:/ / www.pca.state.mn.us/sites/default/files/p-gen2-02.pdf (accessed on 12 August 2017).

4. Sturges, K.; Nicell, J.A. Assessment and regulation of odour impacts. Atmos. Environ. 2009, 43, 196-206. [CrossRef]

5. Naddeo, V.; Zarra, T.; Giuliani, S.; Belgiorno, V. Odour Impact Assessment in Industrial Areas. Chem. Eng. Trans. 2012, 30, 85-90. [CrossRef]

6. Neutra, R.; Lipscomb, J.; Satin, K.; Shusterman, D. Hypotheses to explain the higher symptom rates observed around hazardous waste sites. Environ. Health Perspect. 1991, 94, 31-38. [CrossRef] [PubMed]

7. Mahin, T.D. Comparison of different approaches used to regulate odours around the world. Water Sci. Technol. 2001, 44, 87-102. [PubMed]

8. Van Harreveld, A.P. From odorant formation to odour nuisance: New definitions for discussing a complex process. Water Sci. Technol. 2001, 44, 9-15. [PubMed]

9. Lazarova, V.; Abed, B.; Markovska, G.; Dezenclos, T.; Amara, A. Control of odour nuisance in urban areas: The efficiency and social acceptance of the application of masking agents. Water Sci. Technol. 2013, 68, 614-621. [CrossRef] [PubMed]

10. Taylor, S.M.; Sider, D.; Hampson, C.; Taylor, S.J.; Wilson, K.; Walter, S.D.; Eyles, J.D. Community Health Effects of a Petroleum Refinery. Ecosyst. Health 1997, 3, 27-43. [CrossRef]

11. Luginaah, I.N.; Taylor, S.M.; Elliott, S.J; Eyles, J.D. Community reappraisal of the perceived health effects of a petroleum refinery. Soc. Sci. Med. 2002, 55, 47-61. [CrossRef]

12. Akimoto, H. Global air quality and pollution. Science 2003, 302, 1716-1719. [CrossRef] [PubMed]

13. Kampa, M.; Castanas, E. Human health effects of air pollution. Environ. Pollut. 2008, 151, 362-367. [CrossRef] [PubMed]

14. Ramsay, P.; Thiele, G. Assessment of odour buffer zones for wastewater treatment plants. Clean Air 1995, 29, $48-52$.

15. Belgiorno, V.; Naddeo, V.; Zarra, T. Odour Impact Assessment Handbook; Wiley: Chichester, UK, 2012; ISBN 978-1-119-96928-0.

16. Leonardos, G.; Kendall, D.; Barnard, N. Odor Threshold Determinations of 53 Odorant Chemicals. J. Air Pollut. Control Assoc. 1969, 19, 91-95. [CrossRef]

17. Buttery, B.G.; Turnbaugh, J.G.; Ling, L.C. Contribution of volatiles to rice aroma. J. Agric. Food Chem. 1988, 36, 1006-1009. [CrossRef]

18. Guadagni, G.; Buttery, R.G.; Okano, S. Odour thresholds of some organic compounds associated with food flavours. J. Sci. Food Agric. 1963, 14, 761-765. [CrossRef] 
19. Ruth, J.H. Odor thresholds and irritation levels of several chemical substances: A review. Am. Ind. Hyg. Assoc. J. 1986, 47, 142-151. [CrossRef]

20. Schiffman, S.S.; Bennett, J.L.; Raymer, J.H. Quantification of odors and odorants from swine operations in North Carolina. Agric. For. Meteorol. 2001, 108, 213-240. [CrossRef]

21. Leffingwell, J.C.; Leffingwell, D. GRAS flavor chemicals-detection thresholds. Perfum. Flavor. 1991, 16, 1-19.

22. Fang, J.J.; Yang, N.; Cen, D.Y.; Shao, L.M.; He, P.J. Odor compounds from different sources of landfill: Characterization and source identification. Waste Manag. 2012, 32, 1401-1410. [CrossRef] [PubMed]

23. Lewkowska, P.; Cieślik, B.; Dymerski, T.; Konieczka, P.; Namieśnik, J. Characteristics of odors emitted from municipal wastewater treatment plant and methods for their identification and deodorization techniques. Environ. Res. 2016, 151, 573-586. [CrossRef] [PubMed]

24. Schiavon, M.; Martini, L.M.; Corrà, C.; Scapinello, M.; Coller, G.; Tosi, P.; Ragazzi, M. Characterisation of volatile organic compounds (VOCs) released by the composting of different waste matrices. Environ. Pollut. 2017, 231, 845-853. [CrossRef] [PubMed]

25. Davoli, E.; Gangai, M.L.; Morselli, L.; Tonelli, D. Characterisation of odorants emissions from landfills by SPME and GC/MS. Chemosphere 2003, 51, 357-368. [CrossRef]

26. Nagata, Y.; Takeuchi, N. Measurement of odor threshold by triangle odor bag method. In Odor Measurement Review; Government of Japan: Tokyo, Japan, 2003; pp. 118-127.

27. Anet, B.; Lemasle, M.; Couriol, C.; Lendormi, T.; Amrane, A.; Le Cloirec, P.; Cogny, G.; Fillières, R. Characterization of gaseous odorous emissions from a rendering plant by GC/MS and treatment by biofiltration. J. Environ. Manag. 2013, 128, 981-987. [CrossRef] [PubMed]

28. Amoore, J.E.; Hautala, E. Odor as an aid to chemical safety: Odor thresholds compared with threshold limit values and volatilities for 214 industrial chemicals in air and water dilution. J. Appl. Toxicol. 1983, 3, 272-290. [CrossRef] [PubMed]

29. Gardner, J.W.; Bartlett, P.N. A brief history of electronic noses. Sens. Actuators B Chem. 1994, 18, $211-220$. [CrossRef]

30. Boeker, P. On 'Electronic Nose' methodology. Sens. Actuators B Chem. 2014, 204, 2-17. [CrossRef]

31. Gardner, J.W.; Bartlett, P.N. Performance definition and standardisation of electronic noses. Sens. Actuators B Chem. 1996, 33, 60-67. [CrossRef]

32. Wilson, A.D.; Baietto, M. Applications and advances in electronic-nose technologies. Sensors 2009, 9, 5099-5148. [CrossRef] [PubMed]

33. Munoz, R.; Sivret, E.C.; Parcsi, G.; Lebrero, R.; Wang, X.; Suffet, I.H.; Stuetz, R.M. Monitoring techniques for odour abatement assessment. Water Res. 2010, 44, 5129-5149. [CrossRef] [PubMed]

34. Arshak, K.; Moore, E.; Lyons, G.M.; Harris, J.; Clifford, S. A review of gas sensors employed in electronic nose applications. Sens. Rev. 2004, 24, 181-198. [CrossRef]

35. Rock, F.; Barsan, N.; Weimar, U. Electronic nose: Current status and future trends. Chem. Rev. 2008, 108, 705-725. [CrossRef] [PubMed]

36. Gęicki, J. Application of electrochemical sensors and sensor matrixes for measurement of odorous chemical compounds. Trends Anal. Chem. 2016, 77, 1-13. [CrossRef]

37. Spinelle, L.; Gerboles, M.; Kok, G.; Persijn, S.; Sauerwald, T. Review of Portable and Low-Cost Sensors for the Ambient Air Monitoring of Benzene and Other Volatile Organic Compounds. Sensors 2017, 17, 1520. [CrossRef] [PubMed]

38. Szulczyński, B.; Gębicki, J. Currently Commercially Available Chemical Sensors Employed for Detection of Volatile Organic Compounds in Outdoor and Indoor Air. Environments 2017, 4, 21. [CrossRef]

39. Lee, S.H.; Park, T.H. Recent advances in the development of bioelectronic nose. Biotechnol. Bioprocess Eng. 2010, 15, 22-29. [CrossRef]

40. Wasilewski, T.; Gębicki, J.; Kamysz, W. Bioelectronic nose: Current status and perspectives. Biosens. Bioelectron. 2017, 87, 480-494. [CrossRef] [PubMed]

41. Wu, C.; Wang, L.; Zhou, J.; Zhao, L.; Wang, P. The progress of olfactory transduction and biomimetic olfactory-based biosensors. Chin. Sci. Bull. 2007, 52, 1886-1896. [CrossRef]

42. Gęicki, J.; Dymerski, T.; Namieśnik, J. Investigation of Air Quality beside a Municipal Landfill: The Fate of Malodour Compounds as a Model VOC. Environments 2017, 4, 7. [CrossRef]

43. Postolache, O.A.; Dias Pereira, J.M.; Silva Girao, P.M.B. Smart Sensors Network for Air Quality Monitoring Applications. IEEE Trans. Instrum. Meas. 2009, 58, 3253-3262. [CrossRef] 
44. Chirmata, A.; Ichou, I.A.; Page, T.A. Continuous Electronic Nose Odor Monitoring System in the City of Agadir Morocco. J. Environ. Prot. 2015, 6, 54-63. [CrossRef]

45. Sironi, S.; Capelli, L.; Céntola, P.; Del Rosso, R. Development of a system for the continuous monitoring of odours from a composting plant: Focus on training, data processing and results validation methods. Sens. Actuators B Chem. 2007, 124, 336-346. [CrossRef]

46. Nakamoto, T.; Ishida, H. Chemical sensing in spatial/temporal domains. Chem. Rev. 2008, 108, 680-704. [CrossRef] [PubMed]

47. Bennetts, V.H.; Schaffernicht, E.; Pomareda, V.; Lilienthal, A.J.; Marco, S.; Trincavelli, M. Combining non selective gas sensors on a mobile robot for identification and mapping of multiple chemical compounds. Sensors 2014, 14, 17331-17352. [CrossRef] [PubMed]

48. Guerra, E.; Bolea, Y.; Grau, A.; Munguia, R.; Gamiz, J. A solution for robotized sampling in wastewater plants. In Proceedings of the IECON 2016-42nd Annual Conference of the IEEE Industrial Electronics Society, Florence, Italy, 23-26 October 2016; pp. 6853-6858.

49. Pobkrut, T.; Eamsa-Ard, T.; Kerdcharoen, T. Sensor drone for aerial odor mapping for agriculture and security services. In Proceedings of the 2016 13th International Conference on Electrical Engineering/Electronics, Computer, Telecommunications and Information Technology (ECTI-CON 2016), Chiang Mai, Thailand, 28 June-1 July 2016.

50. Neumann, P.P.; Hernandez Bennetts, V.; Lilienthal, A.J.; Bartholmai, M.; Schiller, J.H. Gas source localization with a micro-drone using bio-inspired and particle filter-based algorithms. Adv. Robot. 2013, 27, 725-738. [CrossRef]

51. Wilson, A.D. Review of Electronic-nose Technologies and Algorithms to Detect Hazardous Chemicals in the Environment. Procedia Technol. 2012, 1, 453-463. [CrossRef]

52. Deshmukh, S.; Bandyopadhyay, R.; Bhattacharyya, N.; Pandey, R.A.; Jana, A. Application of electronic nose for industrial odors and gaseous emissions measurement and monitoring-An overview. Talanta 2015, 144, 329-340. [CrossRef] [PubMed]

53. Russell, R.A.; Bab-Hadiashar, A.; Shepherd, R.L.; Wallace, G.G. A comparison of reactive robot chemotaxis algorithms. Robot. Auton. Syst. 2003, 45, 83-97. [CrossRef]

54. Ishida, H.; Nakamoto, T.; Moriizumi, T. Remote sensing of gas/odor source location and concentration distribution using mobile system. Sens. Actuators B Chem. 1998, 49, 52-57. [CrossRef]

55. Dittman, A.; Quinn, T. Homing in Pacific salmon: Mechanisms and ecological basis. J. Exp. Biol. 1996, 199, 83-91. [PubMed]

56. Martinez, D.; Rochel, O.; Hugues, E. A biomimetic robot for tracking specific odors in turbulent plumes. Auton. Robots 2006, 20, 185-195. [CrossRef]

57. Farrell, J.A.; Pang, S.; Li, W. Plume Mapping via Hidden Markov Methods. IEEE Trans. Syst. Man Cybern. Part B Cybern. 2003, 33, 850-863. [CrossRef] [PubMed]

58. Li, W.; Farrell, J.A.; Pang, S.; Arrieta, R.M. Moth-inspired chemical plume tracing on an autonomous underwater vehicle. IEEE Trans. Robot. 2006, 22, 292-307. [CrossRef]

59. Hayes, A.T.; Martinoli, A.; Goodman, R.M. Swarm robotic odor localization. In Proceedings of the 2001 IEEE/ RSJ International Conference on Intelligent Robots and Systems, Maui, HI, USA, 29 October-3 November 2001; Volume 2, pp. 1073-1078. [CrossRef]

60. Vickers, N.J.; Baker, T.C. Reiterative responses to single strands of odor promote sustained upwind flight and odor source location by moths. Neurobiology 1994, 91, 5756-5760. [CrossRef]

61. Kuwana, Y.; Nagasawa, S.; Shimoyama, I.; Kanzaki, R. Synthesis of the pheromone-oriented behaviour of silkworm moths by a mobile robot with moth antennae as pheromone sensors. Biosens. Bioelectron. 1999, 14, 195-202. [CrossRef]

62. Hernandez Bennetts, V.; Lilienthal, A.J.; Neumann, P.P.; Trincavelli, M. Mobile Robots for Localizing Gas Emission Sources on Landfill Sites: Is Bio-Inspiration the Way to Go? Front. Neuroeng. 2012, 4, 20. [CrossRef] [PubMed]

63. Persaud, K.; Dodd, G. Analysis of discrimination mechanisms in the mammalian olfactory system using a model nose. Nature 1982, 299, 352-355. [CrossRef] [PubMed] 
64. Loutfi, A.; Coradeschi, S.; Karlsson, L.; Broxvall, M. Putting olfaction into action: Using an electronic nose on a multi-sensing mobile robot. In Proceedings of the 2004 IEEE/RSJ International Conference on Intelligent Robots and Systems (IROS 2004), Sendai, Japan, 28 September-2 October 2004; Volume 1, pp. 337-342. [CrossRef]

65. Loutfi, A.; Coradeschi, S. Smell, think and act: A cognitive robot discriminating odours. Auton. Robots 2006, 20, 239-249. [CrossRef]

66. Trincavelli, M.; Reggente, M.; Coradeschi, S.; Loutfi, A.; Lilienthal, A.J.; Ishida, H.; Lilienthal, A.J. Towards Environmental Monitoring with Mobile Robots. In Proceedings of the IEEE/RSJ International Conference on Intelligent Robots and Systems, 2008 (IROS 2008), Nice, France, 22-26 September 2008; pp. 2210-2215. [CrossRef]

67. Wilson, D.M.; Hoyt, S.; Janata, J.; Booksh, K.; Obando, L. Chemical sensors for portable, handheld field instruments. IEEE Sens. J. 2001, 1, 256-274. [CrossRef]

68. James, D.; Scott, S.M.; Ali, Z.; O'Hare, W.T. Chemical sensors for electronic nose systems. Microchim. Acta 2005, 149, 1-17. [CrossRef]

69. Hierlemann, A.; Weimar, U.; Baltes, H. Hand-Held and Palm-Top Chemical Microsensor Systems for Gas Analysis. In Handbook of Machine Olfaction; Wiley-VCH Verlag GmbH \& Co. KGaA: Weinheim, Germany, 2003; ISBN 9783527601592.

70. Gałuszka, A.; Migaszewski, Z.M.; Namieśnik, J. Moving your laboratories to the field—Advantages and limitations of the use of field portable instruments in environmental sample analysis. Environ. Res. 2015, 140, 593-603. [CrossRef] [PubMed]

71. Fuchs, S.; Strobel, P.; Siadat, M.; Lumbreras, M. Evaluation of unpleasant odor with a portable electronic nose. Mater. Sci. Eng. C 2008, 28, 949-953. [CrossRef]

72. Nake, A.; Dubreuil, B.; Raynaud, C.; Talou, T. Outdoor in situ monitoring of volatile emissions from wastewater treatment plants with two portable technologies of electronic noses. Sens. Actuators B Chem. 2005, 106, 36-39. [CrossRef]

73. Abdullah, A.H.; Adom, A.H.; Shakaff, A.Y.M.; Ahmad, M.N.; Zakaria, A.; Saad, F.S.A.; Isa, C.M.N.; Masnan, M.J.; Kamarudin, L.M. Hand-Held Electronic Nose Sensor Selection System for Basal Stamp Rot (BSR) Disease Detection. In Proceedings of the 2012 Third International Conference on Intelligent Systems, Modelling and Simulation (ISMS), Kota Kinabalu, Malaysia, 8-10 February 2012; pp. 737-742. [CrossRef]

74. Ray, H.; Bhattacharyya, N.; Ghosh, A.; Tudu, B.; Bandyopadhyay, R.; Ghosh, A.; Biswas, S.P.; Majumdar, S. Fragrance Profiling of Jasminum Sambac Ait. Flowers Using Electronic Nose. IEEE Sens. J. 2017, 17, 160-168. [CrossRef]

75. Das, A.; Ghosh, T.K.; Ghosh, A.; Ray, H. An embedded Electronic Nose for identification of aroma index for different tea aroma chemicals. In Proceedings of the 2012 Sixth International Conference on Sensing Technology (ICST), Kolkata, India, 18-21 December 2012; pp. 577-582.

76. Hou, C.; Li, J.; Huo, D.; Luo, X.; Dong, J.; Yang, M.; Shi, X. A portable embedded toxic gas detection device based on a cross-responsive sensor array. Sens. Actuators B Chem. 2012, 161, 244-250. [CrossRef]

77. Deshmukh, S.; Kamde, K.; Jana, A.; Korde, S.; Bandyopadhyay, R.; Sankar, R.; Bhattacharyya, N.; Pandey, R. Calibration transfer between electronic nose systems for rapid in situ measurement of pulp and paper industry emissions. Anal. Chim. Acta 2014, 841, 58-67. [CrossRef] [PubMed]

78. Milan, B.; Bootsma, S.; Bilsen, I. Advances in Odour Monitoring with E-Noses in the Port of Rotterdam. Chem. Eng. Trans. 2012, 30, 145-150. [CrossRef]

79. Nicolas, J.; Cerisier, C.; Delva, J.; Romain, A.C. Potential ofa network of electronic noses to assess the odour annoyancein the environment of a compost facility. Chem. Eng. Trans. 2012, 30, 133-138. [CrossRef]

80. Sironi, S.; Capelli, L.; Centola, P.; Del Rosso, R.; Grande, M.I. Continuous monitoring of odours from a composting plant using electronic noses. Waste Manag. 2007, 27, 389-397. [CrossRef] [PubMed]

81. Capelli, L.; Sironi, S. Monitoring odour emisssions from an oil \& gas plant: Electronic nose performance testing in the field. In Proceedings of the ISOEN 2017-ISOCS/IEEE International Symposium on Olfaction and Electronic Nose, Montreal, QC, Canada, 28-31 May 2017; pp. 1-3.

82. Nicolas, J.; Romain, A.C.; Monticelli, D.; Maternova, J.; Andre, P. Choice of a suitable E-nose output variable for the continuous monitoring of an odour in the environment. In Proceedings of the Abstracts ISOEN 2000, Electronic Noses and Olfaction 2000, Brighton, UK, 20-24 July 2000; pp. 127-128. 
83. Elen, B.; Theunis, J.; Ingarra, S.; Molino, A.; Van den Bossche, J.; Reggente, M.; Loreto, V. The Every Aware Sensor Box: A tool for community-based air quality monitoring. In Proceedings of the Sensing a Changing World Workshop, Wageningen, The Netherlands, 9-11 May 2012.

84. Nicolas, J.; Romain, A.C.; Wiertz, V.; Maternova, J.; Andre, P. Using the classification model of an electronic nose to assign unknown malodours to environmental sources and to monitor them continuously. Sens. Actuators B Chem. 2000, 69, 366-371. [CrossRef]

85. Monroy, J.G.; Gonzalez-Jimenez, J.; Sanchez-Garrido, C. Monitoring household garbage odors in urban areas through distribution maps. In Proceedings of the 2014 IEEE SENSORS, Valencia, Spain, 2-5 November 2014; pp. 1364-1367.

86. Pan, L.; Yang, S.X. A New Electronic Nose for Downwind Livestock Farm Odour Measurement. In Proceedings of the 2006 IEEE International Conference on Networking, Sensing and Control, Ft. Lauderdale, FL, USA, 23-25 April 2006; pp. 410-415.

87. Autelitano, F.; Giuliani, F. Analytical assessment of asphalt odor patterns in hot mix asphalt production. J. Clean. Prod. 2018, 172, 1212-1223. [CrossRef]

88. Lilienthal, A.; Duckett, T. A stereo electronic nose for a mobile inspection robot. In Proceedings of the 1st International Workshop on Robotic Sensing, 2003 (ROSE'03), Örebro, Sweden, 5-6 June 2003.

89. Li, J.G.; Sun, B.; Zeng, F.L.; Liu, J.; Yang, J.; Yang, L. Experimental study on multiple odor sources mapping by a mobile robot in time-varying airflow environment. In Proceedings of the 2016 35th Chinese Control Conference (CCC), Chengdu, China, 27-29 July 2016; pp. 6032-6037. [CrossRef]

90. Lim, J.H.; Park, J.; Ahn, J.H.; Jin, H.J.; Hong, S.; Park, T.H. A peptide receptor-based bioelectronic nose for the real-time determination of seafood quality. Biosens. Bioelectron. 2013, 39, 244-249. [CrossRef] [PubMed]

91. Son, M.; Kim, D.; Kang, J.; Lim, J.H.; Lee, S.H.; Ko, H.J.; Hong, S.; Park, T.H. Bioelectronic Nose Using Odorant Binding Protein-Derived Peptide and Carbon Nanotube Field-Effect Transistor for the Assessment of Salmonella Contamination in Food. Anal. Chem. 2016, 88, 11283-11287. [CrossRef] [PubMed]

92. Lee, S.H.; Lim, J.H.; Park, J.; Hong, S.; Park, T.H. Bioelectronic nose combined with a microfluidic system for the detection of gaseous trimethylamine. Biosens. Bioelectron. 2015, 71, 179-185. [CrossRef] [PubMed]

93. Lee, S.H.; Kwon, O.S.; Song, H.S.; Park, S.J.; Sung, J.H.; Jang, J.; Park, T.H. Mimicking the human smell sensing mechanism with an artificial nose platform. Biomaterials 2012, 33, 1722-1729. [CrossRef] [PubMed]

94. Goldsmith, B.R.; Mitala, J.J.; Josue, J.; Castro, A.; Lerner, M.B.; Bayburt, T.H.; Khamis, S.M.; Jones, R.A.; Brand, J.G.; Sligar, S.G.; et al. Biomimetic chemical sensors using nanoelectronic readout of olfactory receptor proteins. ACS Nano 2011, 5, 5408-5416. [CrossRef] [PubMed]

95. Son, M.; Cho, D.G.; Lim, J.H.; Park, J.; Hong, S.; Ko, H.J.; Park, T.H. Real-time monitoring of geosmin and 2-methylisoborneol, representative odor compounds in water pollution using bioelectronic nose with human-like performance. Biosens. Bioelectron. 2015, 74, 199-206. [CrossRef] [PubMed]

96. Kim, T.H.; Lee, B.Y.; Jaworski, J.; Yokoyama, K.; Chung, W.J.; Wang, E.; Hong, S.; Majumdar, A.; Lee, S.W. Selective and sensitive TNT sensors using biomimetic polydiacetylene-coated CNT-FETs. ACS Nano 2011, 5, 2824-2830. [CrossRef] [PubMed]

97. Schütz, S.; Schöning, M.J.; Schroth, P.; Malkoc, Ü.; Weißbecker, B.; Kordos, P.; Lüth, H.; Hummel, H.E. Insect-based BioFET as a bioelectronic nose. Sens. Actuators B Chem. 2000, 65, 291-295. [CrossRef]

98. Liu, F.; Haynes, K.F.; Appel, A.G.; Liu, N. Antennal Olfactory Sensilla Responses to Insect Chemical Repellents in the Common Bed Bug, Cimex lectularius. J. Chem. Ecol. 2014, 40, 522-533. [CrossRef] [PubMed]

99. Brattoli, M.; de Gennaro, G.; de Pinto, V.; Loiotile, A.D.; Lovascio, S.; Penza, M. Odour detection methods: Olfactometry and chemical sensors. Sensors 2011, 11, 5290-5322. [CrossRef] [PubMed]

100. Son, M.; Lee, J.Y.; Ko, H.J.; Park, T.H. Bioelectronic Nose: An Emerging Tool for Odor Standardization. Trends Biotechnol. 2017, 35, 301-307. [CrossRef] [PubMed]

101. Sanmartí, M.; Iavicoli, P.; Pajot-Augy, E.; Gomila, G.; Samitier, J. Human olfactory receptors immobilization on a mixed self assembled monolayer for the development of a bioelectronic nose. Procedia Eng. 2010, 5, 786-789. [CrossRef]

102. Henshaw, P.; Nicell, J.; Sikdar, A. Parameters for the assessment of odour impacts on communities. Atmos. Environ. 2006, 40, 1016-1029. [CrossRef]

103. Bokowa, A.H. The Review of the Odour Legislation. Proc. Water Environ. Fed. 2010, 2010, 492-511. [CrossRef]

104. Gostelow, P.; Parsons, S.A.; Stuetz, R.M. Odour measurements for sewage treatment works. Water Res. 2001, 35, 579-597. [CrossRef] 
105. Guillot, J.; Milan, B. E-noses: Actual Limitations and Perspectives for Environmental Odour Analysis. Chem. Eng. Trans. 2016, 54, 223-228. [CrossRef]

106. Van Harreveld, T.; Guillot, J.; Baas, N.; Bilsen, I.; Bree, F.; Both, R.; Franzen-reuter, I.; Mannebeck, D.; Nicolas, J.; Ogink, N.; et al. Progress of EN13725 revision, the standard used to determine odour concentration and odour treatment efficiency. In Proceedings of the Biotechniques for Air Pollution Control and Bioenergy, Nimes, France, 10-13 September 2013. 